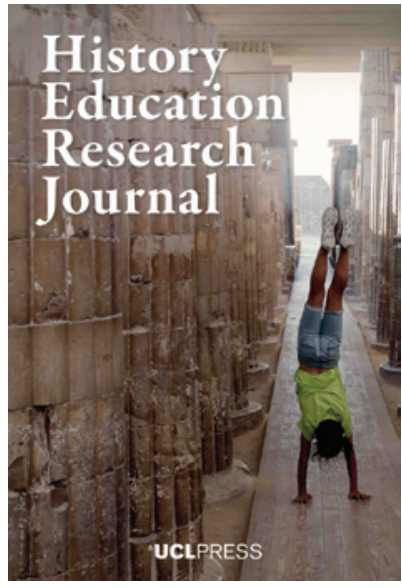

HISTORY EDUCATION RESEARCH JOURNAL

ISSN 2631-9713 (Online)

Journal homepage:

https://www.uclpress.co.uk/pages/history-educationresearch-journal

\title{
Dutch students' understanding of the interpretative nature of textbooks when comparing two texts about a significant event in the development of democracy
}

Annemiek Houwen (D, Carla van Boxtel (iD and Paul Holthuis

\section{How to cite this article}

Houwen, A., Van Boxtel, C. and Holthuis, P. (2020) 'Dutch students' understanding of the interpretative nature of textbooks when comparing two texts about a significant event in the development of democracy'. History Education Research Journal, 17 (2), 214-28. Online. https://doi.org/10.14324/HERJ.17.2.06

Submission date: 16 September 2019

Acceptance date: 15 June 2020

Publication date: 20 October 2020

\section{Peer review}

This article has been peer reviewed through the journal's standard double-blind peer review, where both the reviewers and authors are anonymized during review.

\section{Copyright}

(C) 2020 Houwen, Van Boxtel and Holthuis. This is an open-access article distributed under the terms of the Creative Commons Attribution Licence (CC BY) 4.0 https://creativecommons.org/ licenses/by/4.0/, which permits unrestricted use, distribution and reproduction in any medium, provided the original author and source are credited.

\section{Open access}

The History Education Research Journal is a peer-reviewed open-access journal. 


\title{
Dutch students' understanding of the interpretative nature of textbooks when comparing two texts about a significant event in the development of democracy
}

\author{
Annemiek Houwen* - Drachtster Lyceum and University of Amsterdam, \\ The Netherlands \\ Carla van Boxtel - University of Amsterdam, The Netherlands \\ Paul Holthuis - University of Groningen, The Netherlands
}

\begin{abstract}
In history education, the deconstruction of narratives is an important skill for students. The skill teaches them to look critically at the offered texts. In this study, we investigated the extent to which students are able to critically analyse the narratives in their history textbooks. To answer this question, we asked 106 students in pre-university education (16-17 years of age) to read and compare two texts - from two different textbooks - about a turning point in the development of the Dutch state and democracy: the introduction of universal suffrage for men and women in 1917-19. One group of students $(N=10)$ worked on the assignment while thinking aloud. We found that most students recognized the author's voice in the selection of persons and dates and in the attention paid to a particular topic, but that they hardly mentioned recognizing the voice in aspects such as the choice of words or headings. The students who analysed and compared the texts while thinking aloud all indicated after the assignment that they understood that these texts are different interpretations of the same historical development.
\end{abstract}

Keywords: textbooks; historical thinking; historical interpretation; historical narratives; upper secondary education

\section{Theoretical framework}

It is important that students understand that history is an interpretation and a narrative. Rüsen (2004: 26) describes the historical narrative in the following way:

$[T]$ he linguistic form within which historical consciousness realizes its function of orientation is that of the narrative. In this view, the operations by which the human mind realizes the historical synthesis of the dimensions of time simultaneous with those of value and experience lie in narration: the telling of a story.

There is not one story of the past. Both academic historians and history education researchers have emphasized that the past is interpreted in different ways (for example, Collingwood, 1946; Chapman, 2011; Munslow, 1997). Historians can, for example, explain events, describe the motivations of historical actors and attribute significance to certain events or actions in different ways (Goldman et al., 2016). 
When students better understand that the historical narrative is always an interpretation, they may also become aware of the relevance of the subject of history for, among other things, critical participation in society. The study by Van Straaten et al. (2016) shows that Dutch secondary school students find history to be a less relevant subject. This can be for various reasons, such as the fact that history is not an important subject for obtaining a diploma, where the focus is on Dutch, English and mathematics. However, it may also have to do with the fact that students do not recognize, or insufficiently recognize, the relevance of history. The German FUER model of historical thinking pays explicit attention to the ability to deconstruct historical narratives (Körber, 2015; Trautwein et al., 2017). This is important for critical participation in society. This historical skill is relevant for being able to critically analyse historical representations online and in films, newspapers and museums.

Foster (2012) mentions two common characteristics of history textbooks. First, they often tell a nationalistic story determined by the government. Second, they can present a one-sided, 'best' story, that is, a story from a single perspective. This is problematic because it offers students a selective and one-sided story. It is also contrary to the historical skills that students should develop, including recognizing the interpretative nature of stories about the past. Foster (ibid.: 60) indicates what good history textbooks should be: they 'allow students to appreciate that history is a constructed discipline worthy of interrogation. Good textbooks also allow students to be comfortable with the idea that different versions of the past always will exist.'

In many countries, the history textbook is a leading tool in the classroom, and this also applies to Dutch history education. Of course, we do not know exactly what individual teachers offer their students, but we do know which textbooks are used for lessons and final exams.

In a previous study, the first author analysed two history textbooks in terms of how an important turning point in the development of Dutch democracy, the introduction of universal suffrage in 1917-19, was presented. Two clear conclusions were that little context was given and that students were offered a single story with no multi-perspectivity within the narrative, a finding that is in line with the results of Foster (2012). Furthermore, the two texts gave a different idea of the turning point in 1917-19. These findings raised the question of whether students can approach the textbook as an interpretation. We already know that the interpretation of primary sources, including those in history lessons, is part of a domain-specific skill set (Wineburg, 2001; Reisman, 2012). But what about the interpretation within the textbooks?

Scholars in history education have mainly focused on teaching and learning the ability to read primary history sources. Such research has shown that students mainly focus on the content of historical documents, but that they are not inclined to pay attention to the source and context and whether they corroborate the content (Reisman, 2012; Wineburg, 1991).

We know much less about how students read contemporary accounts of the past, such as textbooks. Textbooks are considered tertiary sources, comparable to compendiums and documentaries, because they are based on both primary and secondary sources (text by historians, such as biographies, articles and monographs) (see Goldman et al., 2016). In addition, history is presented precisely as a set of undisputed facts in texts of this kind.

Lee (2005) reported the results of the CHATA (Concepts of History and Teaching Approaches) project, in which they investigated the understanding of students in Grades 2 to 8 of how there can be different historical accounts of the same event. Approximately 20 per cent of the older students understood that different stories 
answer different questions and did not see a historical account as a copy of the past. Recently, in the Netherlands, Stoel et al. (2017) investigated the epistemological views of 922 students in upper secondary education (ages 17-18) and 7 experts in the field of history. They found that the experts strongly disagreed with items such as 'All history professors will probably give the same answers to questions about the past' and 'There is certainty and singularity in historical knowledge', while the average answers of the students were between 'slightly disagree' and neutral.

The studies by Lee (2013) and Paxton (2002) showed that most secondary school students, regardless of their age, accept the content of textbooks as fact or as factual and that the so-called 'author voice' is not recognized as such by the students.

Research into disciplinary and critical literacy mentions a number of points on which historians' interpretations can be evaluated. For example, Goldman et al. (2016: 18) state:

Evaluations of these arguments are based on choice of evidence presented, the reasoning linking the evidence to the claim, the analytical frameworks used by the historian, and the historian's perspective as embedded in that historian's historical context. Whose voices or perspectives are prioritized? Whose are left out? How coherent and internally consistent is the historical narrative? Does it honour the complexity of human experience?

It is also important to pay attention to the language used in order to get an idea of the author's point of view.

A basic questioning framework for analysing various texts through a critical literacy lens was proposed by McLaughlin and DeVoogd (2004). This framework focuses, for example, on the following: Whose viewpoint is expressed? What does the author want us to think? Whose voices are missing, silenced or discounted? How might alternative perspectives be represented? McLaughlin and DeVoogd (ibid.) asserted that especially by comparing documents or texts (corroboration), one can obtain an idea of each document's perspective. History education scholars Seixas and Morton (2013) stated that students should develop the understanding that historical significance is not intrinsically located in particular events or persons, but is established by means of the narrative constructed by the author. Textbook authors can have different perspectives on the historical significance and the causes and consequences of certain events.

\section{Research questions}

In this study, we focus on Dutch students who take their final exams in history in the pre-university course. According to the examination programme, these students must learn to understand the interpretative character of history and the author's perspective in stories about the past. We have formulated two research questions for this study:

(1) How do pre-university students analyse textbook narratives about the development of Dutch democracy for the period 1917-19?

(2) To what extent are the students able to recognize the narrative in the textbook as an interpretation of this turning point?

\section{Method}

We investigated these questions by giving students assignments based on two textbooks and asking a sample of these students to complete the assignment while thinking aloud. 
Through the thinking-aloud sessions, we aimed to investigate how students made different mental steps in deconstructing different narratives. This was a valuable addition to the content analysis of the written assignments because the students were constantly expressing their thoughts (Schellings, 2012). It was also possible, where necessary, to ask for clarification from the students.

\section{Participants}

A total of five pre-university classes from three schools in the northern Netherlands took part in the study. The total group consisted of 107 students, 59 of whom were girls and 48 of whom were boys. The students were in the twelfth grade (16-17 years of age) and followed a pre-university track in upper secondary education, the highest level of secondary education in the Netherlands. The participating schools were selected from the professional network of the first author, aiming at sufficient variation with regard to denomination and location. The participating schools were a confessional, interconfessional and public school. One school had a regional coverage area, and the other two schools had an urban coverage area.

Participation in the study was voluntary. Of the 107 students, one refused to take part in the study. A total of 96 students participated in the written assignment, and 10 students were asked to perform the same assignment while thinking aloud. The selection of the students to participate in thinking aloud - two students per class - was carried out by their own history teacher. The teachers selected students who had sufficient verbal skills and were sufficiently interested in history to carry out the assignment while thinking aloud.

To interpret the outcomes of the students, experts were asked to carry out the same assignment in writing. The participating experts were all university-educated history teachers. This panel consisted of four history teachers (three men and one woman), one of whom was the teacher of a participating class, in the age range of 27 to 48 years and with teaching experience ranging between 3 and 20 years. They carried out the written assignment in exactly the same way as the students.

\section{The assignment}

All students from the participating classes received texts from two different textbooks about the turning point of 1917-19. This turning point described the introduction of universal suffrage for men in 1917 and for women in 1919. The textbooks described the development of the Dutch state and democracy within the theme, such as the introduction of the first constitution in 1798, the reform of the constitution in 1848, the introduction of universal suffrage for men and women in 1917 and 1919, respectively, and the rise of populism in 2001. This theme is part of the school examination in the Netherlands.

We wanted to investigate the extent to which students recognized the author's perspective in the textbooks and whether this perspective would be easier if they had read and compared a second text on the same subject. The chosen texts differed in size and character. Text 1, from the textbook Memo (Beukers and Klein, 2011) at 478 words, was considerably shorter than text 2, from Geschiedeniswerkplaats (History workshop) (Van der Geugten et al., 2013) at 896 words. In Memo, the topic is a chapter in the textbook, while text 2 is a paragraph of a separate booklet on the development of the Dutch rule of law and democracy. In the Netherlands there is no system of approved history textbooks. Publishing houses produce history textbooks from which teachers can choose. Geschiedeniswerkplaats and Memo are among the most commonly used textbooks in upper secondary education (Van der Kaap and Visser, 2016). Both texts 
contained terms in bold or red. In terms of layout, these terms were aligned with each other so that there was no emphasis on certain terms. The headings remained intact because they indicate the structure of the texts.

The students first read text 1 . They were asked to underline what they considered important in the text. Then, they were asked how they can tell in the text what the writer considers important and asked to illustrate this with an example from the text. They were also asked to write down the causes and consequences mentioned in the text, without the researchers specifically mentioning the introduction of universal suffrage (because students might not identify this as the main topic of the text). We asked students to identify historical events, agents or topics that were considered significant by the author as well as causes and consequences because - as discussed in the theoretical framework - historians can take different perspectives on historical significance and causation. Students were then asked to read text 2 and answered the same questions as for text 1 .

Finally, the written assignment asked for a comparison between the two texts and for a short description of the turning point in their own words. At the end of the assignment, the students who participated in the thinking-aloud session were also asked what they definitely would mention when someone asked them to explain the extension of universal suffrage, and whether their view of school textbooks had changed as a result of the assignment. This last question was only asked in the thinkingaloud session because students could enter into conversation with the researcher so that the experiences of students could be discussed in more depth.

\section{Procedure}

By means of a number of open questions to the students, we determined beforehand whether the students had already dealt with the theme of 'democracy and the rule of law' and which textbook had been used. The students who participated in the thinkingaloud session were also asked these questions in advance. All classes had dealt with the theme earlier in the school year. The students were not already familiar with the texts we presented to them.

The students who participated in the task of thinking aloud were taken out of the regular history lesson by the researcher and taken to a separate classroom. After the researcher explained the assignment and checked whether the assignment was understood, the students were told to start the assignment. Two students per class participated in the thinking-aloud session: the first, while the other students completed the written assignment under the supervision of their own teacher, and the second during another regular history lesson. All assignments were carried out in 50-minute lessons.

\section{Analysis}

First, we looked at which sentences or phrases were most emphasized by students. For the analysis, the sentences or passages used were those that students, in the written assignment, had fully underlined or in which they had underlined more than three words.

Furthermore, using an inductive approach (Miles et al., 2014) and the aspects that historians use to evaluate a historical interpretation as guiding concepts, the first author developed categories for the students' explanation of how one can see what the writer thinks is important. These were discussed with the second and third authors, after which the final categories were defined after a second round of analysis. We formed three categories. 
The first category is the substantive selection made by the author, such as the selection of dates, persons and concepts. The second category describes the attention the author pays to a topic, as evidenced by the use of repetition in the text and the detail with which the historical context of a person or event is described. The third category includes the visual and textual means the author uses to emphasize certain things: the use of punctuation, the use of certain words and an explicit opinion.

To determine the inter-rater reliability of this coding, the responses of 12 students (randomly selected) were coded by a second assessor. For text 1 , these students named 30 indicators (students' answers), and for text 2, they named 24 indicators. For text 1, the percentage of agreement was 90 per cent, and for text 2, the agreement was 75 per cent. The differences between the first and second assessors were mainly related to the subcategory 'attention to the context'.

The thinking-aloud protocols were fully transcribed so that they could be analysed properly. The protocols were analysed in the same way as the written answers, with the same codes. These results were used to clarify and illustrate the written work. Finally, the thinking-aloud protocols provided insight into the students' perspectives with regard to their (changing) views on school textbooks.

The students who took part in the thinking-aloud assignment were identified as students $A$ to $J$. The students who carried out the written assignment were numbered 1 to 96 .

\section{Results}

\section{What students consider important in the text}

All students, both in the written and the thinking-aloud assignments, answered the first prompt: 'Underline what you think is important in the text.' This prompt was very recognizable to the students, as it is an assignment that they are often given when studying a text from a textbook. The students who carried out the written assignment did not explain their choice, but the students who carried out the assignment thinking aloud gave an explanation. This gave an interesting insight into the students' thinking.

Table 1 shows the most frequently underlined sentences. The majority of the students chose those passages in which events with dates were mentioned. All dates and names appearing in the texts were underlined (see Table 1). One example is the following passage: 'In 1894, the Frisian lawyer Pieter Jelles Troelstra founded the SDAP, the Social Democratic Workers' Party.'

The fact that people are considered important is evident from student B's statement: 'A name is mentioned here, Frisian lawyer Pieter Jelles Troelstra, so I always underline in my head the names. He founds a party; universal suffrage was important to him.' That students consider dates in the text to be important is shown by the remark of student E: '1894 Netherlands feminists and women's right to vote to make it clear to me when women started to stand up for themselves.' Finally, the students found those words that give a certain emphasis to be important, such as 'most important', 'great accomplishments' and 'excellent', as in the passage 'Most important point of disagreement was universal suffrage, equality for all and state ownership of the means of production', and the phrase 'the most important point of disagreement was the right to vote, equality for all, and state ownership of the means of production'. The students underlined sentences in which the central subject of the text, the struggle and the introduction of the right to vote were mentioned. However, they did not underline other historical developments mentioned in the text. 


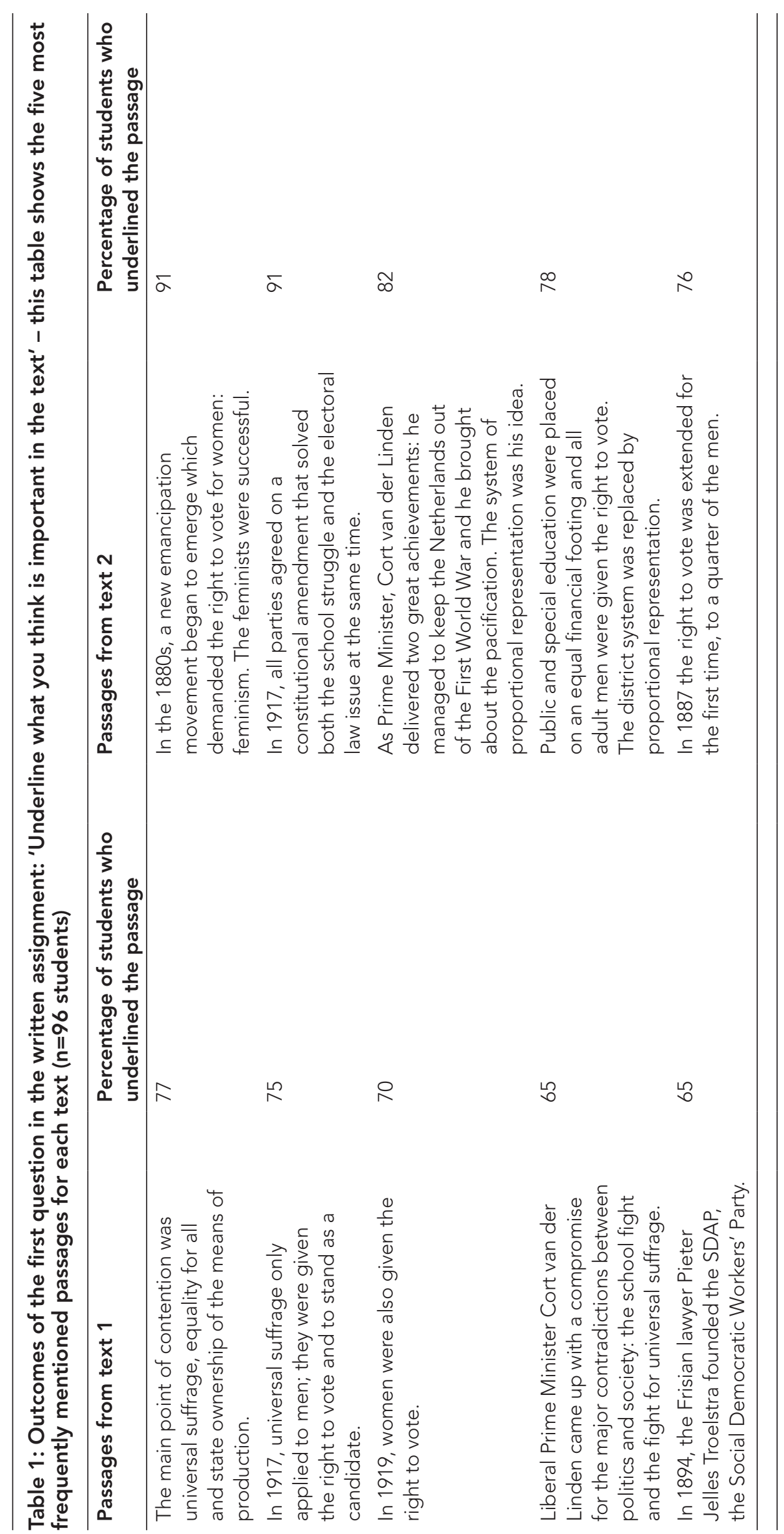


The results of the first question showed hardly any differences between the written and the thinking-aloud assignment. In addition to underlining all persons and years, it is noticeable that in text 2 (Geschiedeniswerkplaats), more students underlined the same passages. This can be explained by the fact that students indicated that text 2 offers more structure, which may have made it clearer to them what was important in the text.

In relation to the first prompt - underline what you find important in the text the experts were more focused than the students on the central topic of the texts; they only underlined the events, persons and years directly related to the extension of the right to vote and its consequences. The experts underlined shorter fragments combined sentences or just words - compared to the students.

\section{The author voice}

The second question was: 'What do you think is important to the writer and how do you see this in the text?'. This question is not often asked during history lessons. This is probably why a number of students found this assignment difficult. For text 1 (Memo), 15 per cent did not complete the assignment, and for text 2 (Geschiedeniswerkplaats), the percentage that did not complete the assignment was even higher, at 22 per cent. The latter was probably due to a lack of time. The students who did the assignment thinking aloud could be helped a little by the interviewer by phrasing the assignment in other words, and all of them completed the assignment.

With the results, we investigated whether the students were able to recognize the perspective of the authors throughout the texts. Table 2 shows the results of the written assignment.

Table 2: Results (frequencies and percentages) of the written assignment 'What do you think is important to the writer and how do you see this in the text?' (for text 1, $n=82$; for text $2, n=75$ )

\begin{tabular}{|c|c|c|}
\hline & $\begin{array}{l}\text { Text } 1 \\
\text { frequency } \\
\text { (percentage) }\end{array}$ & $\begin{array}{l}\text { Text } 2 \\
\text { frequency } \\
\text { (percentage) }\end{array}$ \\
\hline \multicolumn{3}{|l|}{ The substantive selection made by the author } \\
\hline - mentioning of dates & $22(27 \%)$ & $12(16 \%)$ \\
\hline - mentioning of persons & $43(52 \%)$ & $26(35 \%)$ \\
\hline - mentioning of concepts & $13(16 \%)$ & $9(12 \%)$ \\
\hline \multicolumn{3}{|l|}{ The attention the author pays to a topic } \\
\hline - providing historical context for a particular person or event & $19(23 \%)$ & $19(25 \%)$ \\
\hline - use of repetitions & $16(20 \%)$ & $6(8 \%)$ \\
\hline \multicolumn{3}{|l|}{$\begin{array}{l}\text { The visual and textual means used by the writer to emphasize } \\
\text { certain things }\end{array}$} \\
\hline - use of punctuation marks & $12(15 \%)$ & $5(7 \%)$ \\
\hline - the authors' use of words & $13(16 \%)$ & $5(7 \%)$ \\
\hline - headings in the text & $1(1 \%)$ & $13(17 \%)$ \\
\hline - explicit opinion of the authors in the text & $8(10 \%)$ & $9(12 \%)$ \\
\hline
\end{tabular}

From Table 2, it can be concluded that a substantial proportion of the students who completed the written assignment indicated that one can see from the persons the author mentions what the author considers important. The dates mentioned by the 
author were also mentioned by many students. As student 34 said, 'With people like Thorbecke, Kuyper, Schaepman and Suze Groeneweg, the name is mentioned very clearly and deliberately. This is because these people have left something behind and their names (and they themselves) are important.' This was also evident from the thinking-aloud data, as seen in student B's response: 'Certain persons are of course, such as Pieter Jelles Troelstra, often mentioned, at least in the beginning.' It was also clear in the response of student G: 'Well that's Pieter Jelles Troelstra, who is mentioned a few times as leader, so maybe the writer is interested in him because for the others ... yes, who else is mentioned? I don't think too many people are.'

In the written assignment, we found that almost a quarter of the students mentioned the attention the authors pay to a particular topic. Six of the ten students who participated in the thinking-aloud session mentioned the context or space in the text. By this they meant the number of sentences or the detailed description of a topic in the text by which the authors, according to the students, indicated that they considered a topic to be important. Student 40 said: 'Certain events are explained in depth, such as the opinions of the revolutionary socialists. Other important developments are repeated, such as the issue of school struggles and religious education.'

Students also considered the use of punctuation and repetition in the text by the authors to be an indication of importance. As student 42, who carried out the written assignment, writes: 'There are many exclamation marks in the text which show that the writer thinks it is very important (e.g., "but women!").'

Some students recognized the author's opinion in the texts. Student A realized that this might have been the opinion of many Dutch people, but this was not reflected in the text and therefore it seemed to be the opinion of the author. For example, another such phrase is 'the great achievement of Pieter Cort van der Linden'. The writer can also make an event look negative. For example, according to student $B$, the expression 'but women, alla [untranslated] is an interpretation of the writer and gives a negative charge to the description'. Student D said: 'Yes. the choice of words, that it was inevitable. It shows that it was important. And the excellent choice that is mentioned at the Prime Minister Pieter Cort van der Linden. It also shows me that he thought that was important.'

When answering the second question, 'What do you think is important for the writer and how do you see it in the text?', the answers of the experts largely corresponded to the answers of the students. The experts also pointed out the years, people, use of words, attention to context, use of punctuation, author's opinions and use of headings. However, there was one clear difference: two out of four experts mentioned the use of keywords in the text as important, for example: 'He uses keywords to announce a change, for example: new emancipation movement.'

\section{Causes and consequences in the texts}

Causality is important for narrative. The history curriculum states that students should understand that any explanation is an interpretation. The students identified very different events or developments as causes and consequences.

In text 1, many students (44 per cent) mentioned the political cooperation during the First World War as the cause for pacification and thus for the introduction of universal suffrage in the Netherlands. As student $\mathrm{H}$ described it:

That is, the Netherlands was actually quite a country of minorities, where no single movement could have the upper hand, so you had to do business. In order to solve one issue, you had to go along with another. And then all 
parties got together and decided to solve both conflict about the schools and the electoral law issue at the same time. One party went along with the other, and the other party went along with the other so that both could be solved. And that's called the pacification.

In text 2, the students mentioned the struggle for the expansion of electoral rights in Great Britain and the rise of feminism as causes: 60 per cent of the students cited the extension of electoral rights in Great Britain as a cause for the discussions about the extension of electoral rights in the Netherlands, and 53 per cent cited the rise of feminism as the cause.

In both texts, the introduction of the proportional system was mentioned as a consequence by 30 per cent (text 1) and 22 per cent (text 2) of students.

Text 1 described the long-term consequences: 70 per cent of the students mentioned the socialist revolution of Pieter Jelles Troelstra as an important consequence of the introduction of universal suffrage and the associated decreasing influence of the socialists in parliament. For text 2, 30 per cent of the students mentioned the election of Suze Groeneweg as the first woman in the House of Representatives, and the introduction of women's suffrage, as consequences. One example is student F's remark:

Another unintended consequence is actually that women were given the right to vote, because men were given the right to do so, it is likely that women were given the right to vote as well. Yes, the fact that the first woman was elected was also an unintended consequence.

When answering the question about causes and consequences, the experts were more focused than the students on all of the causes and consequences that occurred in the text, instead of only on the causes and consequences for the introduction of universal suffrage. As a result, they identified more causes and consequences in text 2 (the longer text) than in text 1.

\section{A comparison of the texts}

The question 'To what extent do the authors tell the same story?' was only answered by the students who did the written assignment: 70 out of 96 students answered this question.

A large proportion of the students (77 per cent) indicated that the authors were telling the same or largely the same story. Student 15 said, 'Finally, the story of feminism is the same in both texts.' This remark is noteworthy because text 2 devotes a subheading and a separate piece of text to women's suffrage, and text 1 only contains one sentence in which feminism as a concept does not occur at all. As student $Y$ described it, 'Text 1 only mentions feminism. In story 2 , it is a decisive factor.'

The most visible difference was the length of the two texts. Text 1 consisted of 478 words to describe the turning point in 1917, and text 2 used 896 words.

Other differences were mentioned less by students: 10 per cent of the students indicated that text 2 gave more context, 11 per cent of the students indicated the different topics between text 1 and text 2 , and 4 per cent indicated that text 2 was better structured. Student 42 said:

The writers both tell the same story but text 2 gave more context and therefore this text was sometimes easier to understand. Text 1 was also much more focused on the causes and consequences of the parties, and text 2 was much more focused on developments in voting rights. This also gives a different picture. 
Among the experts, this question resulted in major differences in the results. There are similarities in the remarks about the length of the texts, the naming of the electoral law battle and the school struggle. One expert was of the opinion that text 2 was 'more balanced because of the variety of persons and cabinets that are highlighted'. Another expert found that the author of text 1 wanted to place the issue of electoral law more in context, while text 2 hardly did so: 'Text 2 is much more of a bare overview.' The third expert thought that text 2 provided more background information on people and events, which gives a clearer picture: 'In that respect, text 1 is more factual. However, the way in which the author describes the development of electoral law in text 2 is more biased because he clearly shows that he thinks the development is a good thing.' This last interpretation, the author's bias, was not noticed at all by the students.

\section{Own interpretation}

The question: 'What do you think? What would you definitely mention when someone asked you to explain the extension of universal suffrage?' was only asked during the thinking-aloud sessions. Responding to this question, the students mainly mentioned what they missed in the text. There were two things that stood out in the students' answers. First, six out of ten students indicated that they would like to know more about the actions and reactions of the ordinary people themselves. What did the people want? Who demonstrated? What did the banners say? In short, the general opinion of the common people was missed by the students. This indicates that these students would prefer to have more historical context. Second, three of the ten students indicated that it is important to talk about women's suffrage, and that this subject is not given enough attention in the schoolbook texts. Student $F$ made a remarkable statement and created a very personal image of the historical development, filling in the knowledge gap with his own imagination:

But I think especially because men were given universal suffrage, that women were also given universal suffrage because, well, you live with a woman in the house, so you say I also want to say, you are now allowed to vote, I actually want to vote as well. Explain why I shouldn't be allowed to do that. And then everyone actually came to the realization of yes, why is that actually the case. Yes, that's the way I see it, in [text] 1 they just said yes, those men have universal suffrage so women got it too. Here, they explained, well women wanted universal suffrage for a long time and they couldn't get it done and when the men got it done they also said that you know what we want it to be, now it's done. But you can put it, yes it doesn't have to be, but of course it's smart to also say that these women also wanted to have the right to vote. But in the end, it was because of the men, because they have universal suffrage and actually only one woman in parliament, so in the end the universal male suffrage ensured that the women also have the right to vote.

This reasoning indicates that the student created his own context.

\section{Students' understanding of textbooks}

'Has your view of textbooks changed?'. This question, too, was only asked during the thinking-aloud sessions because it was possible for the students to have a conversation with the researcher while answering this question. 
By becoming aware of the differences and similarities between the texts from different textbooks on the same subject, the students came to the realization that the authors determine what and how this is stated in the text. All ten students indicated that this assignment made them look at textbooks in a different way.

Because students are used to working with primary sources in history lessons, they have already become alert to the use of language in primary texts in regard to, for example, propaganda. As student B pointed out, 'Alerted by the lessons on propaganda, I pay particular attention to the use of language in sources.' With this assignment concerning the current texts in history textbooks, students could realize that this is also true for an account in a textbook.

Responding to this question, student $A$ concluded that the textbooks take different angles:

I found this very clear, especially in that comparison between these two texts. How in text 2, even more than in text 1 , the right to vote is seen as a political strategy, and that is really a way of looking at things. Which is also used here in a rather one-sided way, I think, but of course you could also say yes, that is also the part of what the Dutch people really thought in general.

And student J said:

I never thought about it! One book finds another thing [more] important than another book, but that's actually crazy, that they determine for you what's important. Now I'm definitely going to think about it!

That this question can have a major impact on students' views on textbooks became clear after the thinking-aloud session with student $\mathrm{H}$. This student told his teacher that he never realized that authors of textbooks can omit things or can provide colour themselves - in short, that no history textbook will tell the same story. The assignment opened his eyes, and the student wanted to share this discovery with his teacher.

\section{Conclusion and discussion}

In this study, we investigated how pre-university students analysed narratives about the development of Dutch democracy in the period 1917-19 from two different textbooks. Furthermore, we investigated the extent to which the students were able to recognize the narrative in the textbook as an interpretation of that turning point. The results of the assignments showed that students were very focused on persons and years that were mentioned and described in the texts. The choice of certain historical persons by the authors was therefore extremely important for the narrative. The answers to both questions 1 and 2 showed that, for the students, the persons and years shape the narrative.

The question about causes and consequences resulted in many different answers, among both the students and the experts. This can mean that the causes and consequences were difficult to recognize in the texts. The diversity of the answers may also have to do with the fact that the participants (both the students and the experts) did not use the same events as benchmarks. In our assignment, we took the turning point of 1917-19 as a historical event, but this did not appear to be self-evident for all participants.

The findings of our study partly support previous research by Lee (2013), who found that students were not able to recognize the author voice. When answering the 
question of how one can see what the author considers important, students mainly came up with characteristics such as the persons and years that are mentioned and the amount of context that is provided for a particular event or person. A small proportion of students mentioned things such as the words and headlines that a writer uses. The response to the question from students who thought out loud about whether they see textbooks differently, however, showed that by presenting students with different textbooks on the same subject, they can be made to see that the authors are making choices. The results showed that the students are then able to consider the texts, in part, as an interpretation. In this way, they learn to understand the interpretative character of textbooks.

The limitations of this study include the choice of pre-university students. This specific group of students in the Netherlands follows education at the highest level and may be better able to carry out the prescribed assignments than other students of the same age.

The research results may have been influenced by the fact that the students worked on the written assignment in their own classroom with their own history teacher. In all three school lessons, 50 minutes were given for the assignment, but due to the 'noise' around a lesson, some students had less time. This may explain why the assignments around text 2 were not completed by all students.

Subsequently, the teachers selected students who had sufficient verbal skills and were interested in history to carry out the assignment thinking aloud. This means that it was a specific group of students: students at the highest level of secondary education in the Netherlands with a reasonable level of historical thinking and reasoning. The study thus concerns a relatively small group of students.

More research will be needed to see if comparing textbooks is also helpful for understanding the interpretative nature of these texts among students at other levels or from other age groups. This task requires a good level of text comprehension on the part of the students. The selected approach of our study seems promising for helping students recognize the interpretative character of texts as they appear in the textbook. This understanding is not necessarily present among all students (Lee, 2013; Chapman, 2016). Intervention studies could be used to investigate this further.

Our study showed that students are able to recognize the 'author voice' in their textbooks and to recognize the interpretational character when they are asked to identify and explain what the author of the textbook considers significant and when they compare two texts about the same topic. Textbook authors can be more explicit about their choices and interpretative frameworks and clarify that there are multiple possible interpretations. Teachers can occasionally ask students to compare texts from different textbooks to enhance the students' understanding of the interpretative nature of history and their critical literacy skills.

\section{Notes on the contributors}

Annemiek Houwen is a history teacher at Drachtster Lyceum in Drachten, a school for general secondary education in the Netherlands. This study is part of her PhD research 'Ideas of students and historical reasoning: The national past in upper secondary education'.

Carla van Boxtel is a professor in history education at the University of Amsterdam. Her research focuses on the teaching and learning of history in and outside school. She has published widely about the teaching and learning of historical reasoning. 
Paul Holthuis was a lecturer in pedagogy and history didactics at the University of Groningen, the Netherlands (2002-16). He was a history teacher at a Dutch secondary school from 1975 till 2013. He has written various books and articles about history and didactics.

\section{References}

Beukers, E. and Klein, S. (eds) (2011) Memo. Geschiedenis voor de bovenbouw. WWO leer/ opdrachtenboek. s'Hertogenbosch: Malmberg.

Chapman, A. (2011) 'Twist and shout? Developing sixth-form students' thinking about historical interpretation'. Teaching History, 142, 24-33.

Chapman, A. (2016) Developing Students' Understanding of Historical Interpretation. Oxford: Edxecel/Pearson.

Collingwood, R.G. (1946) The Idea of History. Oxford: Clarendon Press.

Foster, S. (2012) 'Re-thinking history textbooks in a globalized world'. In Carretero, M., Asensio, M. and Rodriquez-Moneo, M. (eds) History Education and the Construction of National Identities. Charlotte, NC: Information Age Publishing, 49-62.

Goldman, S.R., Britt, M.A., Brown, W., Cribb, G., George, M., Greenleaf, C., Lee, C.D., Shanahan, C. and Project READI (2016) 'Literacies and learning to read for understanding: A conceptual framework for disciplinary literacy'. Educational Psychologist, 51 (2), 1-28. Online. https://doi.org/10.1080/00461520.2016.1168741

Körber, A. (2015) 'Historical consciousness, historical competencies - and beyond? Some conceptual development within German history didactics'. Online. www.pedocs.de/ volltexte/2015/10811/pdf/Koerber_2015_Development_German_History_Didactics.pd (accessed 5 July 2020).

Lee, M. (2013) 'Promoting historical reasoning using the explicit reasoning text'. The Journal of Social Studies Research, 37 (1), 33-45. Online. https://doi.org/10.1016/j.jssr.2012.12.003

Lee, P. (2005) 'Putting principles into practice: Understanding history'. In Donovan, S. and Bransford, J.D. (eds) How Students Learn: History, mathematics, and science in the classroom. Washington, DC: The National Academies Press, 31-78.

McLaughlin, M.E. and DeVoogd, G. (2004). Critical Literacy: Enhancing students' comprehension of text. New York: Scholastic.

Miles, M.B., Huberman, A.M. and Saldaňa, J. (2014) Qualitative Data Analysis. A methods sourcebook. Thousand Oaks, CA: Sage.

Munslow, A. (1997) Deconstructing History. London: Routledge.

Paxton, R.J. (2002) 'The influence of author visibility on high school students solving a historical problem'. Cognition and Instruction, 20 (2), 197-248. Online. https://doi.org/10.1207/ S1532690XCl2002_3

Reisman, A. (2012) 'Reading like a historian: A document-based history curriculum intervention in urban high schools'. Cognition and Instruction, 30 (1), 86-112. Online. https://doi.org/10.1080/07 370008.2011.634081

Rüsen, J. (2004) 'Historical consciousness: Narrative structure, moral function, and ontogenetic development'. In Seixas, P. (ed.) Theorizing Historical Consciousness. Toronto: University of Toronto Press, 63-85.

Schellings, G.L.M. (2012) 'Zicht op leren door hardopdenken'. In Kluwer Navigator Onderwijs. Online. https://pure.tue.nl/ws/files/78319005/hardopdenk_methode_Kluwer_ def_20120319T111859.pdf (accessed 28 September 2020).

Seixas, P. and Morton, T. (2013) The Big Six Historical Thinking Concepts. Toronto: Nelson Education.

Stoel, G., Logtenberg, A., Wansink, B., Huijgen, T., Van Boxtel, C. and Van Drie, J. (2017) 'Measuring epistemological beliefs in history education: An exploration of naïve and nuanced beliefs'. International Journal of Educational Research, 83, 120-34. Online. https://doi.org/10.1016/j.ijer.2017.03.003

Trautwein, U., Bertram, C., Von Borries, B., Brauch, N., Hirsch, M., Klausmeier, K. and Zuckowski, A. (2017) Kompetenzen historischen Denkens erfassen: Konzeption, Operationalisierung und Befunde des Projekts. Münster: Waxmann.

Van der Geugten, T., Schröer, P. and Verkuil, D. (eds) (2013) Geschiedeniswerkplaats. Rechtsstaat en democratie. Geschiedenis van de rechtsstaat en van de parlementaire democratie. WWO. Groningen/Houten: Noordhoff. 
Van der Kaap, A. and Visser, A. (2016) Geschiedenis: Vakspecifieke trendanalyse 2016. Enschede: SLO.

Van Straaten, D., Wilschut, A. and Oostdam, R. (2016) 'Making history relevant to students by connecting past, present and future: A framework for research'. Journal of Curriculum Studies, 48 (4), 479-502. Online. https://doi.org/10.1080/00220272.2015.1089938

Wineburg, S. (1991) 'Historical problem solving: A study of the cognitive processes used in the evaluation of documentary and pictorial evidence'. Journal of Educational Psychology, 83 (1), 73-87. Online. https://doi.org/10.1037/0022-0663.83.1.73

Wineburg, S. (2001) Historical Thinking and Other Unnatural Acts: Charting the future of teaching the past. Philadelphia, PA: Temple University Press. 